Animal Health Research Institute,

Dokki, Giza, Egypt.

\title{
IN VITRO AND IN VIVO CHARACTERIZATION OF SOME PATHOGENIC MICROORGANISMS ISOLATED FROM BROILERS IN BEHERA PROVINCE WITH SPECIAL REFERENCE TO THE EFFECACY OF ALLIUM SATIVUM "GARLIC" (With 4 Tables)
}

\author{
By \\ A.F. ABDEL MOGHNEY \\ (Received at 16/6/1998)
}



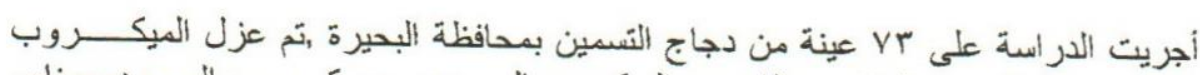

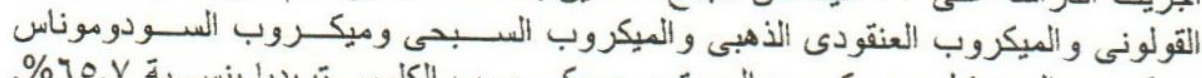

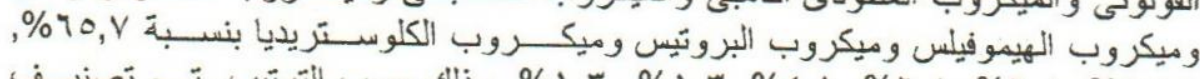

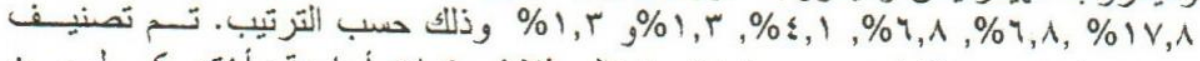

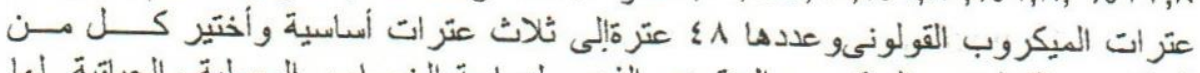

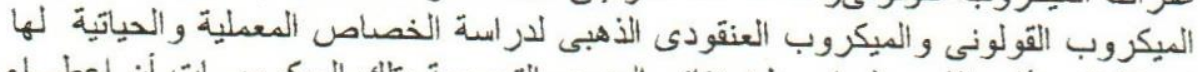

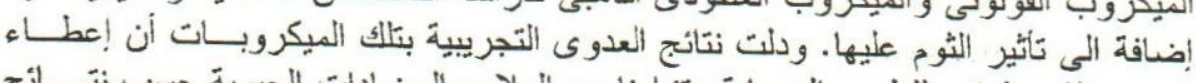

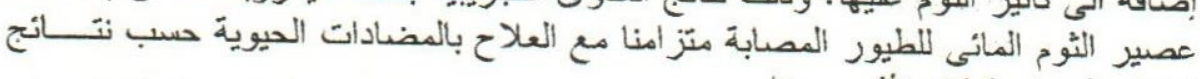

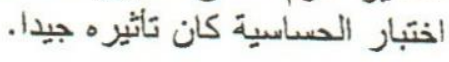

\section{SUMMARY}

The study was carried out on 73 samples of broilers in Behera Province, The isolated Microorganisms were E.Coli, Staph.aureus, Streptococcus avium, Pseudomonas spp., Haemophilus paragalinarum, Proteus vulgaris, Clostridia spp. with an incidence of 65.7, 17.8, 6.8, $6.8,4.1,1.3,1.3$, percent respectively. The In vitro and In vivo characterization of some pathogenic microorganisms (E.ColiStaph.aureus) were studied with special reference to the effecacy of 
Allium sativum "Garlic", the best results were seen when both Garlic and the effective antibiotic were used.

\section{Key Words: Broilers, Allium Sativum, Garlic}

\section{INTRODUCTION}

One of the important factor affecting poultry industry is disease particularly on intensive production. Coliform infection (E.coli) plays a part include colisepticaemia, colibacillosis, chronic respiratory disease, air saculitis, yolk sac and navel infection resulting in significant losses. While Staphylococcosis refers to the various diseases of poultry and other avian species caused primarily by the bacterium Staphylococcus aureus causing lameness, swollen joints, spondolitis, subdermal staphylococcal abscesses, gangrenous dermatitis and staphylococcal septicaemia (Prukner, 1986; and Jensen and Skeeles 1989).

Among baby chicks, broilers and laying hens different E.coli serotypes $026,055,086,0111,0114,0119,0125,0126,0127,0128,0142$, and 0158 were isolated by many investigators, (Sahar 1994; Torky et al., 1995).

Immunosuppression may contribute to the cause of complex diseases and immunization failures. Immunosuppression may increase a bird's susceptibilty to infection and to development of disease, and it may allow infectious agents to persist (Winterfield, 1989).

Control measures of E.Coli associated diseases were mostly relying on prophylactic measures and use of the therapeutic agents, However, increase of antibiotic resistance has been encountered on many sites where outbreaks have been occuring repeatidly (Rosenberger and Cloud, 1985). Antibiotic multiresistant which can resist more than one type of antibacterial agent is considered now as an acutual hazard both in human and/or Veterinary medical fields (Werner, 1986)

The misuse of antibacterials, and other antimicrobial agents have many side effects. However the herbal therapy if found to be effective serves at both synergist and corrective factors, the antibacterial properties of Allium sativum (Garlic) were studied by

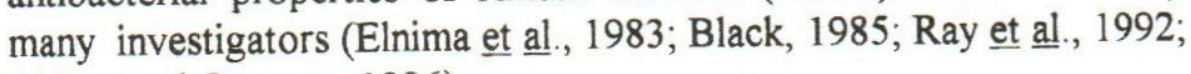
Ahlam and Omayma 1996). 
Investigations of antibacterial activity in plants particularly those largely consumed by humans is highly indicated because it may be considered in the future an effective, available and inexpensive source of antibacterial agent especially under the new international economic system (GAT) so, The aim of the present study was to discuss the character of most common microorganisms causing problems in broiler industry in Behaira province and the antibacterial effecacy of Allium sativum on these microorganisms.

\section{MATERIALS and METHODS}

\section{Material:}

A total of 73 samples from broiler private farms were collected, the birds were sent directly to the laboratory, sacrified and examined bacteriologicaly for isolation and identification of pathogenic microorganisms.

\section{Culture media:-}

Trials for isolation of bacteria were carried out by culturing on, blood agar,chocolate blood agar, broth nutrient agar, Manitol salt phenol-red agar, Baird parker's medium, Christen's urea agar, MacConkey's agar, peptone water, MacConkey broth, Glucose phosphate broth, nutrient broth, malonate broth, simmon citrate agar, Triple sugar iorn agar.

\section{Reagents:}

Gram's stain, Kovac's reagent, urea, Methyle red in absolute ethanol, rabbit plasma, $\mathrm{H}_{2} \mathrm{O}_{2} 3 \%$.

\section{Antisera:-}

The serological identification of E.coli was done using monovalent E.coli antisera produced by "Behring" against $\mathrm{K}$ and $\mathrm{O}$ antigens.

\section{Sensitivety discs:}

A-Antibiotic discs (ABD): commercial antibiotic discs produced by (Oxoid) includes: (Amoxycillin "Aml" 20mcgEnrofloxacin "En" 5mcg-spictinomycin "Sp" 100mcg-gentamycin "Gm" 10mcg-streptomycin "S"10mcg-flumequene "Ub" $30 \mathrm{mcg}$ neomycin "N"30mcg-oxytetracyclin "Ot" $30 \mathrm{mcg}$ ) and (lincospectin "Lin" $100 \mathrm{mcg}$ which produced by Upjhon)- were used in this investigation. 
B-Garlic discs (g): Sterile discs of Whatman filter paper were impregnated in aquaous garlic juice.

C-Antibiotic garlic discs (ABGD): was prepared after impregnation of the commercial antibiotic discs (Oxoid)\&(Upjhon) in aquous garlic juice to take the symboles (Amlg-Enrg-Spg-Gmg-SgUbg-Ling-Ng-Otg)

\section{Methods:}

\section{Isolation,purification and identification of the isolates:}

After surface sterilization of Liver, spleen and heart of freshly sloughtered birds, it were minced,using a sterile loop, a streaking over plates of blood agar, MacConkey's agar and Nutrient agar was occured, the inoculated plates were incubated at $37{ }^{\circ} \mathrm{C}$ for $18-24$ hours . The colonies were examined according to their growth on various media, Films were prepared from the suspected pure isolates and stained with Gram's stain then examined microscopically ,the identification were carried out using the criteria adopted by Merchant and Packer (1969), Edwards and Ewing (1972), Cruckshank et al.,(1975), Finegold and Martin (1982).

\section{The in vitro and invivo sensitivity test:}

Sixty one serovares of the bacterial isolates ( 48 were related to E.coli and 13 isolates of Staph.aureus strain) were used in this test using (ABD-GD-and ABGD).

\section{Experimental procedures:}

Sixty, one day old broiler chicks were kept under hygienic condition, they divided to 6 groups each of 10 chicks in a separate floor pen (A-B-C-D-E-F). The groups (A-C-E) at 6 day old were infected via the oral route with $1 \mathrm{ml}$ of the isolated Staphylococcus aureus strain containing a total count of $1.2 \times 10^{6}$, the other groups (B$\mathrm{D}-\mathrm{F}$ ) were infected also via the oral route with $1 \mathrm{ml}$ of the isolated E.coli strain $0114 \mathrm{~K}-(\mathrm{C})$ containing a total count of $1.2 \times 10^{6}$, all the groups were treated as illustrated in table (1): 
Assiut Vet. Med. J. Vol. 39 No. 78, July 1998.

Table 1. Experimental procedure:

\begin{tabular}{|c|c|c|c|c|}
\hline \multicolumn{5}{|c|}{ Treatment at } \\
\hline Group & Day 3.5 old & Day 6 old & day 7.9 old & day $10-12$ old \\
\hline A & $\begin{array}{l}\text { Garlic juice in } \\
\text { drinking water }\end{array}$ & $\begin{array}{l}\text { oral infection with } \\
\text { Staph aureus }\end{array}$ & $\begin{array}{l}\text { garlic juice in drinking } \\
\text { water }\end{array}$ & No medication \\
\hline $\bar{B}$ & $\begin{array}{l}\text { Garlic juice in } \\
\text { drinking water }\end{array}$ & $\begin{array}{l}\text { oral infection with F coli } \\
\text { "0114k-(C) }\end{array}$ & $\begin{array}{l}\text { garlic juice in drinking } \\
\text { water }\end{array}$ & No medication \\
\hline C & no medication & $\begin{array}{l}\text { oral infection with } \\
\text { Staph aureus }\end{array}$ & no medication & $\begin{array}{l}\text { Garlic juice in drinking wa } \\
\text { + systemic ensofloxa } \\
\text { "Cidotril-CII) Co.-Egy } \\
\text { according to Sensitivity tes }\end{array}$ \\
\hline $\bar{D}$ & no medication & $\begin{array}{l}\text { oral infection with E.coli } \\
\text { "0114k-(C) }\end{array}$ & no medication & $\begin{array}{l}\text { Garlic juice in drinki } \\
\text { water+systemic enrofloxa } \\
\text { "Cidotril-CID Co.-Egy } \\
\text { according to Sensitivity test }\end{array}$ \\
\hline$E$ & no medication & $\begin{array}{l}\text { oral inforlinn with } \\
\text { Staph aureus }\end{array}$ & no merlication & $\begin{array}{l}\text { Systemic enrofloxa } \\
\text { "Cidotril-CID Co-Fgy } \\
\text { according to Sensitivity test }\end{array}$ \\
\hline$\vec{F}$ & no medication & $\begin{array}{l}\text { ornl infection with } \\
\text { () } 114 \mathrm{k} \text {.(C) }\end{array}$ & nn medication & $\begin{array}{l}\text { Systemic enrofloya } \\
\text { Cidntril-( }) \text { (o.-Fgy } \\
\text { according to Sensitivity test }\end{array}$ \\
\hline
\end{tabular}

The chicks were kept under observation, sacrified birds were taken for reisolation and typing the isolated serovar after the treatment course according to Finegold and Martin(1982).

\section{RESULTS and DISCUSSION}

As shown in table (2) it was found that the pathogenic microorganisms isolated were as follows: Echerichia coli (48/73) in an incidence of $65.7 \%$, Staphylococcus aureus (13/73) with an incidence of $17.8 \%$, Haemophilus paragalinarum $(5 / 73)$ with an incidence of $6.8 \%$, Streptococcus avium (5/73) with an incidence of $6.8 \%$, Pseudomonas spp (3/73) in an incidence of $4.1 \%$, Clostredial spp. $(1 / 73)$ in an incidence of $1.3 \%$, Proteus vulgaris (1/73) in an incidence of $1.3 \%$ which means the most common pathogenic microorganisms were E.coli and Staphylococcus aureus.

The serotyping of the E.coli strains $(\mathrm{No}=48)$ revealed three serotypes which represented as $[055 \mathrm{~K} 59(\mathrm{~A})(\mathrm{No}=24 / 48)-0114 \mathrm{~K}-(\mathrm{C})$ No. $=(13 / 48)$, and $086 \mathrm{~K} 61(\mathrm{~B})$ No. $=(11 / 48)]$.

The In vitro sensitivity test (table 2 ) for the 48 different strains of E.coli [055K59(A)- $0114 \mathrm{~K}-(\mathrm{C}), 086 \mathrm{~K} 61(\mathrm{~B})]$ revealed that a $37.5 \%, 20.8 \%, 20.8 \%$ and $16.6 \%$ of these isolates were sensitive to 
enrofloxacin, spectinomycin, lincospectin, and flumequine respectively, moreover the sensetivity to Garlic (GD) revealed an $83.3 \%$, while the sensitivity to (ABGD) ranged between 91.6-100\%. Our results coincids with many authors (Hassan and Shawkat, 1982; Abonorage et al., 1992; and Ahlam and Omayma 1996) who reported a powerful bactericidal action of Allium sativum extract on E.coli.

On respect to Staphylococcus aureus it revealed a sensitivity of $100 \%, 83.3 \%, 33.3 \%$ to amoxycillin, enrofloxacin and lincospectin respectively. While the Garlic (GD) showed intermediate effectivness, this results disagree with Abonorage, et al.,(1992) who reported high effecacy of garlic extract on Staph.aureus.

In contrast the (ABGD) showed a synergistic action represented in an $100 \%, 100 \%, 66.6 \%, 66.6 \%$ and $50 \%$ inhibition with (amoxycillin, enrofloxacin, spectinomycin, lincospectin and gentamycin).

The experimental infection to the chicks with serovars $0114 \mathrm{~K}$ (C), and Staph.aureus with oral route showed a morbidity rate of $100 \%$ in all groups after 72 hours of the infection except group Aand B which showed (4/10) $40 \%$ morbidity in each, which means that garlic reduced the morbidity rate when offered to this groups (A-B) three days before and after infection through its antibacterial action and stimulation of the host's defense mechanism. Petkov, (1985) reported that Garlic was found to stimulate the reticuloendothelial system of treated animals.

The sacrified birds from group ( $\mathrm{B}, \mathrm{D}$, and $\mathrm{F})$ showed sever congested lungs airsaculitis, perihepatitis, enlarged heart muscles, enlarged gall bladder. These results agree with these of Butura et al., (1973). while the subcutaneous haemorrhages, peticheal haemorrhage on thigh, brest the provent, and coloaca, with nicrotic focci in liver were the most prodominant in the sacrified birds from groups $(\mathrm{A}, \mathrm{C}$, and $\mathrm{E})$ the In vivo results (table 3 ) revealed a highly synirgistec action of garlic juice when offered in drinking water with the systemic injection of enrofloxacin (Cidotril) which used according the In vitro sensitivity test represented as failure of reisolation of the infected strain $(0114 \mathrm{~K}-(\mathrm{C})$ (Group D), from the sacrified birds while a few scattered colonies (4 colonies) of Staph aureus could be isolated from the sacrified bird (groupC). That means the garlic juice when used in parallel to the effective antibiotic have a powerful synergistic action. These findings were in complete agreement with the results of 
Ahlam and Omayma (1996) who reported that the watery extract of Allium sativum juice evoked high antibacterial effects against most of bacterial strains.

The results in group (B-F) a very small number (12, to 14 colonies) of E.Coli strain $0114 \mathrm{~K}-(\mathrm{C})$ could be isolated, In case of group (A-E) the number of colonies which reisolated were much more (47and 44 Staph.aureus colonies) respectively.

In conclusion the using of Garlic juice alone (group A-B) was not completely satisfied to overcome the infected pathogens (E.coliStaph.aureus), the same results for the antibiotic group (E-F) but the best results were seen when both Garlic and the sensitive antibiotic were used so it is so important to put garlic on its right position through further investigations.

The misuse of antibacterial agents especially in the small private broiler industry have many side effects, since the key pathogen for the flock disease is the E.coli and from the obtained results we can advice in prophylactic measures the periodic using of garlic juice in broiler flocks can be an alternative path way to many antibiotcs and in combination with the effective antibiotics in cases of problems sustain its antibacterial action, on the other hand it may help to some extent in minimizing the risk of bacterial resistance to the antibacterial in both human and veterinary fields.

\section{REFERENCES}

Abonorage,M.A.M;Selim.I.B.A; and Hanafy,M.S.M.(1992): Some studies on the antimicrobial activity of garlic (Allium Sativum) BeniSuef, Vet.Med.Res.Vol.2., No.1., 238-246.

Ahlam,A.A.and Omayma,I.K.(1996): Studies on the effects of Hibiscus Subdariffa; Allium Sativum and Negilla Sativa on some bacterial isolates of chickens. 7th Sci.Cong.17-19 Nov. Fac. Vet. Med. Assiut. Egypt. 245-251.

Black,E.(1985): The chemistry of garlic and onion.Scientific american 252; 114-119.

Butura, I.C. and Whenham,C.R.(1973): Epidemiological and experimental studieson E.coli infection of poultry (fowl). Medicina Veterimara, 27:313-320. 
Cruickshank,R.,Duguid,J.P.I.;Marinion, B.P. and Swain, R.H.A. (1975): Medical Microbiology 12th Ed. Vol.II Churchill Livignstone Edinburgh, London and New York.

Edwards,P.R. and Ewing, W.H.(1972): Identification of enterobacteriaceae 2 nd Ed.

Elnima,E.T; Ahmed,S.A.; Mekkawi,A.G.; Mossa, J.S.(1983): The antimicrobial activity of garlic and onion extracts.Pharmazie. 38:11, 747-748.

Finegold,S.M.and Martin,W.J.(1982): "Diagnostic Microbiology" 6th ed.Rhe.C.V. Mosby Company, London.

Hassan, A.B. and Shawkat,M.E. (1982):Antimicrobial activity of some edible plants.J.Anim.Hltb.Afr.30, 245-249.

Jensen,M.M.and Skeeles,J.K.(1989): "Staphylococcosis" In a laboratory manual for the isolation and identification of avian pathogens. 3rd ed. pp 43-44.Published by the American association of avian pathologists.

Merchant,I.A. and Packer, R.A.(1969): Veterinary Bacteriology and Virology. 7th Ed. Lowa state college press, Ames, Lowa, U.S.A.

Petkov,V.(1985): Bulgarian traditional medicine a source of ideas for phytopharmacological investigations. Journal Ethnopharmacology $15,121-132$.

Prukner,E.(1986): Frequency epidemiological significance of virulent Escherichia coli strains in dead poultry in Yugoslavia and their sensitivity to antimicrobial agents. Veterinarski archiv. 56(5): 227-237.

Rosenberger,J.K.and Cloud ,S.S.(1985): Characterization of Echerichia coli isolates from Deimarva broiler chickens.

Proc.16th Nath.Meet. Poult.Health and Eandemn. Delmar, Md.P.104.

Roy,J; Khan,I.H.; Dutta,A.K.; Sarker,M.H. Choudhuri,S.K. and Mahmoud,M.(1992): Bangaladesh Renal J.Vol.11 (1) 13-17.

Sahar,A..Fakar, (1994): Epizootiological studies on E.coli infection in broiler chickens.ph.D.thesis, Fac.Vet.Med. Cairo Univ.

Torky,H.A.;El-Nimr,M.M.H.;Akeila,M.A.;Moussa,M.M.I;Aly,A.B. and Mona Sahaly (1995): Isolation of E.coli from broiler chickens.Alex.J.Vet.Sci., Vol.11,No.4,577-585 (1stSCVMR).

Werner, E. (1986): Topical aspects of the use of antibiotics in cattle .Monatshefte fur Veterinar Medizen 41, 685-690. 
Winterfield,R.W.(1989): In a laboratory manual for the isolation and identification of avian pathogens. 3rd ed. pp 1-2.Published by the American association of avian pathologists

Table 2. Incedence of the pathogenic microorganisms isolated from Broilers In Behera Province

\begin{tabular}{|l|l|l|l|}
\hline \multicolumn{1}{|c|}{ Microorganism } & No. & Serotyping & \multicolumn{1}{c|}{ Percent } \\
\hline E.coli & 48 & $\begin{array}{l}\text { 055K59(A)-NO=24 } \\
0114 \mathrm{~K}(\mathrm{C})--\mathrm{No}=13 \\
\text { 086K61(B)_No=11 }\end{array}$ & 65.7 \\
\hline Staphylococus aureus & 13 & & 17.8 \\
\hline Streptococcus avium. & 5 & & 6.8 \\
\hline Pseudomonas spp. & 5 & & 6.8 \\
\hline Haemophilus paragalinarum & 3 & & 4.1 \\
\hline Proteus vulgaris & 1 & & 1.3 \\
\hline Clostridia spp. & 1 & & 1.3 \\
\hline Total & 73 & & 100 \\
\hline
\end{tabular}

\section{Table 3. The in vitro sensitivity test to the different serovars of E.Coli \& Staph.aureus.}

\begin{tabular}{|c|c|c|c|c|c|c|c|c|c|c|c|c|c|c|c|}
\hline & \multicolumn{3}{|c|}{$\begin{array}{l}055 \mathrm{K5} 9(\mathrm{~A}) \\
\left(\mathrm{No}_{0 .}=24\right)\end{array}$} & \multicolumn{3}{|c|}{$0114 \mathrm{~K}(\mathrm{C})(\mathrm{Ne} .=13)$} & \multicolumn{3}{|c|}{$086 \mathrm{~K} 61(\mathrm{~B})($ No. $=11)$} & \multicolumn{3}{|c|}{ Total Nom 48} & \multicolumn{3}{|c|}{$\begin{array}{l}\text { Total No. of } \\
\text { Staph_aureus (13) }\end{array}$} \\
\hline & 8 & $i$ & $r$ & $s$ & $r$ & $s$ & 1 & $\mathrm{R}$ & $\mathrm{s}$ & $s$ & $\mathrm{i}$ & $r$ & $\mathrm{~S}$ & $\mathrm{i}$ & $r$ \\
\hline Aml & 4 & 8 & 12 & 7 & 7 & 2 & 3 & 6 & 9 & & 14 & 25 & 4 & 3 & 6 \\
\hline Amig & 24 & & & 13 & & 11 & & & 48 & & & & & & \\
\hline Enr & 12 & 12 & & 6 & 2 & 3 & 6 & 2 & 21 & & 23 & & 5 & 5 & 3 \\
\hline Enrg & 24 & & & 13 & & 11 & & & 48 & & & & & & \\
\hline $\mathrm{Sp}$ & 4 & 4 & 16 & 2 & 7 & 1 & 5 & 5 & 7 & & 16 & 28 & 1 & 2 & 10 \\
\hline Spg & 24 & & & 13 & & 11 & & & 48 & & & & & & \\
\hline $\mathrm{Gm}$ & 4 & 16 & 4 & 3 & 4 & 1 & 6 & 5 & 8 & 28 & 12 & & 2 & 5 & 6 \\
\hline Gmg & 24 & & & 13 & & 11 & & & 48 & & & & & & \\
\hline $\mathrm{S}$ & & 4 & 20 & & 13 & & & 11 & 48 & & & & & & \\
\hline $\mathrm{Sg}_{\mathrm{g}}$ & 24 & & & 13 & 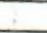 & 11 & & & 48 & & & & & & \\
\hline $\mathrm{Ub}$ & 4 & 4 & 16 & 5 & 6 & 1 & 4 & 6 & 10 & 10 & 24 & & 2 & 3 & 8 \\
\hline $\mathrm{Ub}$ & 24 & & & 13 & & 11 & & & 48 & & & & & & \\
\hline Lin & 4 & 12 & 8 & 5 & 3 & 2 & 5 & 4 & 9 & 17 & 25 & & 2 & 3 & 8 \\
\hline Ling & 24 & & & 13 & & 11 & & & 48 & & & & & & \\
\hline $\mathrm{N}$ & & 8 & 16 & & 4 & & 4 & 7 & & 21 & 27 & & 1 & 1 & 11 \\
\hline $\mathrm{Ng}_{\mathrm{B}}$ & 24 & & & 13 & & 11 & & & 48 & & & & & & \\
\hline $\mathrm{Ot}$ & & & 24 & & 13 & & 1 & 10 & & 1 & 47 & & & 1 & 12 \\
\hline $\mathrm{Otg}_{\mathrm{g}}$ & 24 & & & 13 & & 11 & & & 48 & & & & & & \\
\hline G & 24 & & & 13 & & 11 & & & 48 & & & & & & \\
\hline
\end{tabular}

I=intermediate

$r=$ resist 
Assiut Vet. Med. J. Vol. 39 No. 78, July 1998.

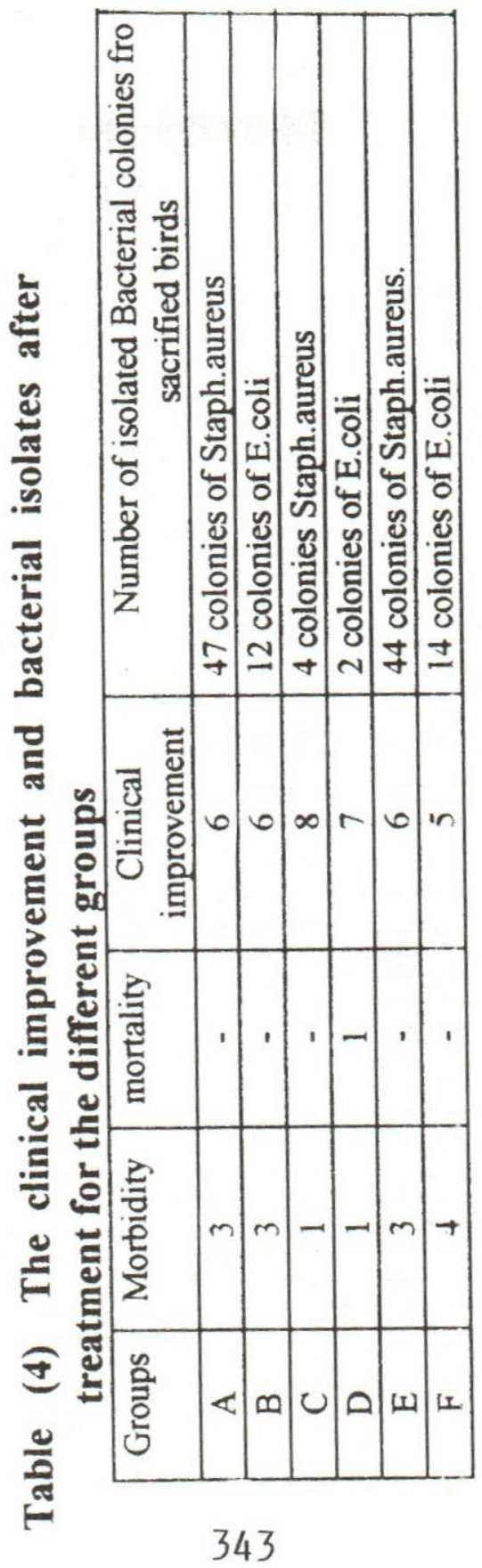

